\title{
BARIŞ MANÇO ŞARKILARININ VİKTOR FRANKL PSİKOLOJİ EKOLÜ AÇISINDAN DEĞERLENDİRILMESI
}

\section{EVALUATION OF BARIŞ MANÇO SONGS IN TERMS OF VICTOR FRANKL PSYCHOLOGY SCHOOL}

\author{
Uğur KESKİN ${ }^{1}$
}

$\ddot{O_{z}}$

Bu makalede, Avusturyalı psikiyatr Viktor Frankl'ın sanatsal yönelişlere ilişkin bakış açısı üzerinde durulmuştur. Makalede, Frankl'ın genel anlamda sanat, özel anlamda ise müzik alanına ilişkin izah, yorum ve değerlendirmelerine yer verilmiştir. Müzik sanatının bileşenleri arasında yer alan ve müziğin söylemsel yönünü teşkil eden şarkı sözü içeriklerinin, psikolojik boyutu incelenerek, Frankl'ın bakış açısı biraz daha özele indirgenmeye çalışılmıştır. Bu kapsamda, Barış Manço’nun şarkı sözleri, Frankl'ın birincil kaynak eserleri kapsamında incelemeye konu edilmiştir. Nitel araştırma yöntemlerinden içerik incelemesi tekniğinin benimsendiği çalışmada, Frankl’ın özgün bakış açısı ekseninde değerlendirmeler yapılmıştır. Makalenin sonucunda, sanatsal çalışmaları, bilimsel çalışmalardan ayrı kılan dört temel bileşenin varlığını ileri süren Frankl'ın bu görüşünün, Manço'nun seslendirmiş olduğu şarkılar kapsamında anlamlı bir şekilde desteklenmekte olduğu belirlenmiştir. Keşifsel bir çalışma olarak bu makale, benzer bir anlayış çerçevesinde yürütülecek olan gelecek çalışmalar için katkılar sunabilecek tartışma ve değerlendirmeleri okuyucunun dikkatine sunmuştur.

Anahtar Kelimeler: Müzik, Şarkı Sözleri, Psikoloji, Viktor Frankl, Barış Manço.

\begin{abstract}
In this article, the point of view of the Austrian psychiatrist Viktor Frankl on artistic orientations is emphasized. In the article, Frankl 's general meaning of art, and in particular the field of music, commentary and evaluation of the field has been included. Frankl's point of view has been attempted to be reduced to a more special point by examining the psychological dimension of the lyrics content, which are among the components of music and which constitute the discursive aspect of music. In this context, Barlş Manço's lyrics were examined in the context of Frankl's primary source works. In the examinations using the content analysis technique of qualitative research methods, Frankl's original perspective was evaluated. As a result of this article, it is determined that this view of Frankl, who asserts the existence of the four
\end{abstract}

\footnotetext{
${ }^{1}$ Doç. Dr., Anadolu Üniversitesi, ugurkeskin@anadolu.edu.tr
} 
basic components that differentiate the artistic works from scientific studies, is supported in a meaningful way within the scope of the songs performed by Manço. As an exploratory study, this article presents the reader with the help of controversies and evaluations that may contribute to future studies in a similar manner.

Keywords: Music, Lyrics, Psychology, Viktor Frankl, Barış Manço.

\section{GíRiş}

Viyana ekolünden gelen Psikiyatr Viktor Frankl, bu ekolün üçüncü kuşağını temsil etmektedir. Viyana ekolünün psikoloji alanındaki ilk kuşağının öncülüğünü Sigmund Freud yapmıştır. İkinci kuşağın başta gelen temsilcisi olarak ise Alfred Adler ön plana çıkmaktadır. Frankl, bu iki öncülden sonra gelen üçüncü kuşağı olarak kabul edilmektedir. Frankl, Viyana ekolü içindeki yerini şu sözlerle ifade etmektedir (Frankl, 2018a: 111): "Viyana'daki büroma gelip "söyleyin doktor, siz psikanalist misiniz?" diye soran bir doktora "Tam anlamıyla psikanalist değil ama psikoterapist diyelim” diye karşılık verdim. Bunun üzerine soru sormayı sürdürdü: "Hangi ekolü savunuyorsunuz?" Ben de "Kendi teorimi; adına logoterapi deniliyor" diye yanıtladım".

Yukarıdaki ifadelerinde Frankl, kendi bakış açısının, psikoloji alanındaki diğer ekollerden farklı olarak özgün bir konuma sahip bulunduğunu ifade etmektedir. Frankl'ın bu konumu, psikoloji çevrelerinde ve literatürde genel bir geçerlilik kazanmış bulunmaktadır (Frankl, 2018b, s. 9). Frankl'ın yaklaşımı; hümanistik psikoloji kategorisinde değerlendirilmekte, fenomenolojik ya da varoluşçu psikiyatriyle özdeşleştirilmektedir (Frankl, 1999, s. 112).

Freud (2011, s. 37), insanın, "haz istenci” olarak adlandırdığı temel bir motivin itkisi ile hareket ettiğini ileri sürmektedir. Adler (1996, s. 40; 2011, s. 170; 2012a, s. 64; 2012b, s. 100) ise, Hobbes (2014, s. 21; 2017, s. 75) ve Nietzsche (1997, s. 137-141; 2014, s. 27-28) gibi realist düşünürlerin "güç istenci" olarak adlandırdığı motivi, "üstünlüğe ulaşma çabası" olarak kavramlaştırmaktadır. Freud ve Adler’i "derinlik psikolojisi”nin temsilcileri olarak nitelendiren Frankl ise, kendi bakış açısını "yükseklik psikolojisi” olarak tanımlamaktadır (Frankl, 2014a, s. 98). Frankl'ın bu anlayışını destekleyen Oskar Pfister, şunları ifade etmektedir (Frankl, 2014a, s. 99): "Derinlik psikolojisiyle karşılaştırıldığında daha önemli olan insanın doğasının derinlikleri gibi kuvvetli olan tinsel yüksekliklerini kabul etmektir”. Sonuç olarak, Frankl öncesi psikoloji ekollerinin, insanın sanatsal yönlerini kapsayan bakış açısının oldukça uzağında kaldığını ifade etmek mümkün olabilmektedir.

Frankl, "den başka bir şey değil"cilikten mazoşistçe haz alan indirgemeci (redüksiyonist) davranışçı veya psikodinamik modeli benimseyen psikologların, insandaki gizli yüceliği, ideale, güzele, değerlere ulaşma çabasını küçümseme eğilimlerini eleştirmektedir. Ortaya konulan eserlerin arka planındaki şartlanma süreçlerini, itkileri, içgüdüleri araştıran psikolojik çalışmaları kapalı bir anlayış (1999, s. 67), bir tür "ifşa etme" çabası ve gerçekten insanca olan şeylere yönelik "bilinçsiz küçümseme ihtiyacı" olarak değerlendirmektedir (Frankl, 2014b, s. 158; Frankl, 2018a, s. 114). Frankl, bu konuda şu ifadeleri kullanmaktadır: "İnsanın 'çıplak bir maymun'dan; idin, egonun ve süper egonun oyun alanından; itkilerin ve içgüdülerin piyonu ve oyuncağından; şartlanma ve öğrenme süreçlerinin ürününden; sosyoekonomik koşulların, rahatsızlıkların ve komplekslerin kurbanından başka bir şey olmadığını” (Frankl, 1999, s. 86) 
söyleyen indirgemeci yaklaşımların, insan kalbinin bilgeliğine ve (Frankl, 1999, s. 57) yüksek soyutlama düzeyini temsil eden sanatsal yönelişlerine bakış açısı da aynı ölçüde kusurlu olmaktadır. İnsan kapalı bir hücre (monad) değildir ve insanın dünyaya açıklığını kavramadığı sürece psikoloji, bir tür hücre bilime (monadoloji) dönüşmektedir (Frankl, 1999, s. 49-50).

Frank1, olaylara bakış açısını alabildiğine genişletmeyi amaçlamaktadır. "Sadece psikolojik olanın alacakaranlığı, bütün nesneleri grileştirir”" (Frankl, 2014b, s. 209) ifadesi, Frankl’ın bu yaklaşımını veciz bir şekilde ifade etmektedir. Kendisi de psikoloji alanında yer alan bir bilim insanı olmasına karşılık bu sözüyle Frankl, olaylara sadece psikoloji ekseninde bakmanın yeterli olmayacağını belirtmektedir. Frankl'a göre, psikoloji alanındaki ekollerin hepsi, olgulara kendi bakış açıları üzerinde aşırıya kaçan bir tek yanlı vurgulama yapmaktadırlar. Bu durum, yani salt psikoloji bakış açsının, üstelik de ait bulunulan psikoloji ekolü ekseninde ortaya konulan bakış açısının alacakaranlığı, yalnızca görülen nesneleri bulanıklaştırmakla kalmayıp, onların şeklini de deforme etmektedir. Frankl, söz konusu deformasyonu "Prokrustes yatağı" benzetmesi ile açıklamaktadır (Frank1, 2014b, s. 209). Bilindiği üzere Antik Yunan mitolojisinde haydut Prokrudes, insanları bir yatağa yatmaya mecbur etmektedir. Uzuvları yataktan taşanları kesmekte, kısa olanları ise gererek, çekerek uzatmaktadır. Sonuçta yatağın boyu, insanların boyuna uymaktadır fakat bu insanlar, insanlıktan çıkarak kurbana dönüşmektedirler. Frankl, bu benzetmeyle, insanı belirli kalıpların içine sokmaya çalışan psikoloji ekollerini ağır bir şekilde eleştirmeyi amaçlamaktadır. Frankl, özellikle sanatsal konulara indirgemeci bir yaklaşım gösterenlere, Einstein'den yaptığı aşağıdaki alıntıyı nakletmektedir.

Einstein'a bir keresinde "Her şeyin günün birinde doğa bilimleri tarzıyla ifade edilebileceğine inanıyor musunuz?" diye sorduğunda, "Evet, düşünülebilir bir durum bu ama manasız” der. "Hiç de uygun olmayan ifade etmek olur bu; tıpkı bir Beethoven senfonisini hava basıncı grafik eğrileriyle göstermek gibi” (Frankl, 2014b, s. 194).

Antik Yunan; kültür, felsefe, bilim ve bu anlamda müziğin kökenini barındıran bir uygarlıktır. Çin, Hint ve Mezopotamya'da kurulmuş olan ilkçağ uygarlıklarından farklı olarak ve onlardan aldıklarıyla bugünkü müziğin temelini oluşturmuştur (Akan, 2012, s. 58). Antik Yunan'da söyleme dayalı sanatların, mitolojik kökene dayandığı bilinmektedir. Bu sanatların ortaya konduğu mitolojik/dinsel mekân ise Dionysos mabedi olmuştur (Güntekin, 1976, s. 137-138). Aiskhylos, Sophokles, Euripides ve Aristophanes gibi ozanlar, mitolojik şarkıları tragedyaya dönüştürerek Yunan tiyatrosunun temellerini atmışlardır (Güntekin, 1976, s. 145). Bu ozanlar şarkı sözlerini, günümüzde mitoloji denilen fakat Yunanlıların, geçmişin tarihi olarak kabul etmiş oldukları ve kuşaktan kuşağa aktarılan öykülerden almışlardır (McNeill, 2003, s. 216). Antik Yunan yazınsal oyunlarının (tragedya ve komedyaların), karşılıklı diyaloglar şeklinde yapılandırılmış olması, Platon ve Aristoteles'in eserlerinin de diyaloglar şeklinde keleme alınmasına kaynaklık etmiştir.

Platon (2010, s. 82); sözün, müziğin ayrılmaz bir parçası olduğunu vurgulayan erken dönem düşünürlerin başında yer almaktadır. Platon'un müzik konusundaki görüşlerinde ise Pisagor'un büyük bir etkisi bulunmaktadır. Pisagor'dan günümüze ulaşan yazılı bir eser bulunmadığı için, Pisagor’un müzik konusundaki görüşlerine, en eski birincil kaynak eser olarak Laertios’un (2017, s. 385), üçüncü yüzyılda yazdığı Ünlü Filozofların Yaşamları ve Öğretileri adlı kitabında ulaşılabilmektedir. Pisagor, telli çalgılar 
üzerinde çalışmalar yürütmüş ve ses aralıklarının, tel üzerinde aritmetik oranlarla ifade edilen uzunluklara karşl1ık geldiğini görünce, müzikteki bu uyumun, evrendeki genel ve yetkin uyumu temsil ettiğinin teminatı olarak kabul ederek (Cevizci, 2000, s. 784) bu armoni görüşünü, evrenin bütününe egemen olacak şekilde genelleştirmiştir. Pisagor sonrası başlıca müzik kuramcıları şunlar olmuştur: Philolaus, Archytas, Aristoxenus, Erastosthenes, Didymos, Ptolemy, Cleonides, Aristides Quintilianus (Akan, 2012, s. 86).

Antik dönemlerden itibaren genel olarak sanata, özel olarak ise müzik sanatına olumlu yaklaşan düşünürlerden bazıları şunlar olmuştur: Pisagor (Laertios, 2017, s. 385), Platon (2010, s. 82), Aristoteles (2008, s. 240; 2017, s. 30), Seneca (2017, s. 35-37), Plutarkhos (2002, s. 45), Farabi, (1955, s. 100-101), Nasiruddin Tusi (2007, s. 193-194), Sadi Şirazi (2004, s. 246), Nizami, (2009, s. 53-54), Montaigne (2011, s. 72), Kinalızade Ali Efendi (2011, s. 47), Thomas More (2011, s. 47), Desiderius Erasmus (2007, s. 44; 86), Tommaso Campanella (2011, s. 73; 101), Denis Diderot ve Jean Le Rond D'alembert 2005, s. 209; 261), Friedrich W. Nietzsche (1997, s. 30; 114), Arthur Schopenhauer (2008, s. 57-58), Nikolay Vasilyeviç Gogol (2017, s. 88; 97), Abraham H. Maslow (1996, s. 93), Bertrand Russell (2004, s. 26).

Ünlü filozof Sinoplu Diyojen'e göre müzik, geometri, astronomi ve benzeri konular yararsız ve gereksiz olduğu için göz ardı edilebilir bir niteliğe sahip bulunmaktadır (Laertios, 2017, s. 281). Diyojenik bakış açısıyla genel olarak sanata, özel olarak ise müziğe olumsuz yaklaşan bazı düşünürler ise şu şekilde sıralayabilmek mümkündür: Diyojen (Laertios, 2017, s. 281), Boethius (2006, s. 103), Jean-Jacques Rousseau (1997, s. 18), Edwin A. Abbott (2016, s. 17), Hermann Hesse, (1994, s. 44).

Platon'un çağdaşı olan Diyojen'den itibaren genel anlamda sanat, özelde ise müzik alanına bakış konusunda, ikici (düalist) bir yol ayrımı olmuşmuş bulunmaktadır. Bu yol ayrımının bir tarafinda sanatı olumlayan, diğer tarafinda ise onu olmusuzlayan görüşler yer almakta olduğu görülebilmektedir. Söz konusu ayrımı biraz daha belirginleştirebilmek için filozoflar, bakış açılarına (kendi birincil kaynak eserlerinde yer vermiş oldukları görüşler doğrultusunda) ve kronolojilerine uygun olarak yukarıda sıralanmıştır. Müzik sanatına olumlu ve olumsuz yönden yaklaşan düşünürlere ilişkin yukarıdaki örnekleri artırabilmek mümkün olmakla birlikte, bu sanata bakış açısının genel anlamda olumlu olduğunu ifade edebilmek olası gözükmektedir. Müzik sanatını olumlu yönden ele alan Frankl'ın bakış açısı ve onun bakış açısı doğrultusunda yürütülen Barış Manço şarkılarının içerik incelemesine yönelik ayrıntılara ise aşağıdaki anlatımlarda yer verilmiştir.

\section{LITERATÜR ÖZETI}

Müzik yazınında, müziğin kendi dinamikleri üzerine çok sayıda bilimsel yayın yapılmış bulunmasına karşılık, müziğin ayrılmaz bir bileşeni olan şarkı sözleri kapsamındaki çalışmalar, görece daha sınırlıdır. Oysa şarkı sözleri, klasik sanat dalları arasında yer almakta olan müziğin önemli bir bileşenini oluşturmaktadır. Yıldırım ve Koç (2011, s. 56), müzik ve söz ilişkisini şu şekilde ifade etmişlerdir: "Baktı̆̆ımızda insan dil yetisinin sınırları içinde davranıyor ve dil yetisi de insan sesinde kendi anlatımını buluyor. Ses varlığı olarak insan kendi dilsel müziğini yaratıyor. Kısacası; tümce bir ses oyunudur ve müzik de bu oyunun adı".

Müziğin ses temelli yönlerini ortaya koyan bilimsel çalışmaların başlıca vurguları, kendi alanı içinde teknik denilebilecek uzmanlık alanlarını ön plana çıkarmaktadır. Literatürde, şarkı sözlerini çeşitli 
açılardan ele alan çalışmalara rastlanmasına karşılık, konuyu psikolojik bakış açısıyla araştıran çalışmaların azlığı dikkat çekmektedir (Yalçın ve Voltan Acar, 2006; Gençtanırım ve Voltan Acar, 2007). Hiçbir ilave anlatıma yer verilmeyip, sadece belirli sanatçı veya müzik grubunun şarkı sözlerine yer verilen yayınlara (Uygun, 2000) rastlanabildiği gibi, şarkı sözlerini seslendiren sanatçı veya grup ile ilgili ayrıntılı anlatımların yer aldığı yayınlara da (Akkılıç, 1995) rastlanabilmektedir. Ses sanatçılarını konu edinen bazı yayınların ise, asıl vurguyu sanatçının şarkı sözleri üzerinde yapmayıp, sanatçının çeşitli yönlerini ele almakta oldukları görülmektedir (Dikici, 2005; Dikici 2017; Işık ve Işık, 2013; Şanlıdağ, 2016). Buna karşılık, tekil bir sanatçı özelinde ve belirli bir bilimsel bağlam kapsamında yürütülen çalışmalar göreceli olarak sınırlı kalmaktadır. Sıralanan nedenlerden dolayı bu makale, psikoloji ve müzik bilimleri alanlarında keşifsel anlamda katkılar sağlamayı ve gelecekte yapılacak daha kapsamlı çalışmalara öncülük etmeyi hedeflemektedir. Makalede, sanatsal faaliyetleri dörtlü bir ayrım kapsamında (öğretici, vaaz veren, mantık yürüten, ahlaki değer canlandıran) ele alan Frankl'ın bakış açısı, şarkı sözü içeriklerine (Barış Manço şarkıları özelinde) yönelik psikolojik açıklama mekanizması olması bakımından incelemeye konu edilmiştir.

\subsection{Viktor Frankl ve Ekolü Hakkında Genel Bilgiler}

Avusturyalı psikiyatr Frankl; Freud ve Adler sonrası çalışmalarıyla hem onların takipçisi, hem de onlardan ayrılan yönleri bakımından üçüncü kuşak Viyana ekolü temsilcisi olarak kabul edilmektedir. Frankl, kısa süren Freud ve Adler ekolü eksenindeki çalışmalarından sonra yaptığı bütün bilimsel çalışmalarını "anlam” ve "değer" temelli olarak gerçekleştirmiştir. İnsanı, anlam arayışı sürecinde yönlendiren başat unsurun "vicdan” olduğunu ifade eden Frankl, vicdanın, insanın anlam organı olduğunu ileri sürmüştür (Frankl, 2014a, s. 85).

Frankl, kendi yaklaşımının ahlakçı ve entelektüel değil, fenomenolojik çözümlemelere dayalı olduğunu ifade etmektedir (Frankl, 2018b, s. 89). Frankl, yaşamda anlam bulunabilecek durumları şu şekilde açıklamaktadır (Frankl, 2018b, s. 89; 2014a, s. 90; 2014b, s. 23; 75): İnsan; bir eser yaratarak (hayatın içine bir eser koyarak), iş yaparak, bir eylemi eyleyerek ya da iyiliği, hakikati, güzelliği deneyimleyerek; doğayı veya kültürü deneyimleyerek şimdi-burada-varoluşuna anlam kazandırabilmektedir. Dikkat edilirse Frankl, yaşamın anlamını bulma çabasına ilişkin verdiği örneklerin başına "eser yaratma” eylemini koymaktadır. Şarkı sözleri de sanatsal eser yaratma biçimlerinden biri olması yönüyle, Frankl'ın bütün bilimsel çalışmalarının ortak vurgusu olan insanın anlam arayışı bakımından belirgin bir nitelik taşımaktadır. Frankl, "anlam” kavramının ahlaki bir zemine değil, fenomenolojik/ampirik bir zemine dayandığını ileri sürerek, bu türden verilere ulaşabilmek için yapılması gerekenin, insanın (bu makale özelinde düşünüldüğünde şarkı sözü yazarlarının) anlamları ve değerleri deneyimlediği yöne dönüp bunu bilimsel dile çevirmek olduğunu belirtmiştir (Frankl, 2018b, s. 88). Bu açıdan bakıldığında, Barış Manço’nun seslendirdiği eserlerin söz yazarlarının "anlamları ve değerleri deneyimlediği yöne dönme" konusunda yüzde yüzlük bir doğrulukla ulaşabilmek mümkün görünmemektedir. Söz konusu zorluğa rağmen yine de bu makalede, söz yazarlarının, şarkı sözlerini hangi amaç, bağlam, ruh hali ve diğer çevresel şartlar altında kaleme aldıkları değerlendirilmeye çalışılmıştır. 


\subsection{Viktor Frankl'ın Sanata/Müziğe Yaklaşımı}

Çok önemsiz gibi görünen bir ayrıntı bile (mizah, sanat vb.) hoşnutluğa neden olabilmektedir diyen Frankl (2018a, s. 59), bunu şöyle bir örnekle açıklamaktadır: Bir insanın hoşnut olması veya acı çekmesi, boş bir odadaki gazın davranışına benzer. Boş bir odaya belli bir miktarda gaz verildiği zaman, oda ne kadar büyük olursa olsun, gaz odanın tamamına yayılır. Dolayısıyla insanın algıladığı hoşnutluk veya estetik algıların seviyesi görecelidir. Söz konusu göreceliliği de göz önünde bulunduran Frankl, sanatsal çalışmalara yönelik olarak mutlak reçeteler, çözümler veya cevaplar oluşturmak gibi iddialı bir söylem geliştirmemiştir. Frankl, kendi yaklaşımının cevap sunmak değil, aslında daha ziyade bir katalizör görevi üstlenmek olduğunu ifade etmektedir (Frankl, 2018b, s. 61).

Frankl'ın bakış açısından sanatsal uğraşılar, bireyin anlam arayışı sürecinde yöneldiği başlıca uğraşılardan birini teşkil etmektedir. Frankl (2014b, s. 16), her şeyden önce, karikatürist olması yönüyle, sanatsal uğraşılara karşı olumlu bir yaklaşıma sahip bulunmaktadır. Otobiyografisinde bu yönünü şu sözlerle ifade etmektedir: "Bir karikatürist ve psikiyatrist olarak insanların zaaflarının farkına varıyorsunuz". Frankl (2014b, s. 48), sanatçının, toplumsal anlamda üstlenmesi gereken rolü ise şu şekilde dile getirmektedir: "Birinin sadece laflarla değil, de eylemle, yaratıcılıkla örnek olması önemlidir".

Hayatın anlamı sorusuna, yaratılan bir eserle karşıllk verilebileceğine yönelik Frankl’ın görüşüne yukarıdaki anlatımlarda yer verilmiştir. Frankl (2014b, s. 57), bu konuda aşağıdaki örneği vermektedir:

Farz edelim bir konser salonundasınız ve çok sevdiğiniz senfonilerden birini dinliyorsunuz ve kulaklarınızda o senfoninin en sevdiğiniz bölümleri peş peşe sıralanıyor; öyle kapılmışsınız ki, zaman zaman ürperdiğinizi hissediyorsunuz. Şimdi psikolojik olarak mümkün olmayanın, bu düşünce eyleminde mümkün olduğunu kabul edelim ve birisi kalkıp size tam böyle ürperdiğiniz anlardan birinde "Hayatın anlamı var mı?” diye sorsun. Sanıyorum şunu iddia edecek olursam bana hak verirsiniz: Bu durumda sadece tek bir cevap verebilirsiniz ve o da şu olur: "Sırf bu anı yaşamış olduğuma değdi hayat!” Bu sanatı yaşamayı bilen kimse için geçerlidir.

Şark1 sözü yazma gibi sanatsal/edebi uğraşıları, "tamamlanmamış bir iş" olarak nitelendiren Frankl'ın bakış açısı, bu tür yaratıcı uğraşılardan emekli olunamayacağını, sağlığın elverdiği ölçüde, hatta (kişisel ideal, anlam ve değerler uğruna) adanmışlık düzeyinde sürdürülmesi gerektiğini vurgulamaktadır (Frankl, 2014b, s. 237; Frankl, 2018a, s. 95; 113). Frankl'a göre, bu sorumluluğun bilincine varan kişi, yaşamını, dolayısıyla da üretici yaşamını aktif bir şekilde sürdürmeye devam edecektir. Frankl, bu konudaki düşüncesini şu sözlerle ifade etmektedir (2018a, s. 95): “Tamamlanmamış bir işe yönelik sorumluluğunun bilincine varan kişi, yaşamını kesinlikle bir yana itemeyecektir. Varoluşun 'nedeni'ni bilecek ve hemen her 'nasıl'a dayanabilecektir". Frankl'dan yapılan bu iki cümlelik alıntının birincisi kendisine, ikincisi ise Nietzsche'den yaptığ 1 bir alıntıya dayanmaktadır.

Frankl; yaşamın tüm yönlerinin, özellikle de belirli bir amaç ve ideale yönelmiş olan sanatsal çalışmaların kalıcı olduğu vurgusunu yapmaktadır. Frankl (1999, s. 107), bu hususu şu sözlerle açıklamaktadır: "Her şey kalıcıdır (sonsuzdur). Daha da önemlisi, kendinden kalıcı olur. Bu konuda bir şey yapmamız gerekmez. Bir şeyi yarattıktan sonra, işi kalıcılık devralır”.

Frankl'ın akış açısından ele alındığında şarkı sözlerini oluşturan dil, kendini anlatmaktan öte şeyleri ifade etmektedir. Dil her zaman için kendi ötesindeki şeyleri göstermektedir, başka deyişle kendini 
aşkın bir niteliğe sahip bulunmaktadır. İnsan olmak, kendi dışında bir şeye, gerçekleştirilecek bir anlama yönelmeyi gerekli kılmaktadır. Kendini görmeyen sağlıklı bir göz (kataraktlı bir göz, bulutlanma gibi bir şey görür, bu kendi kataraktıdır) gibi, insan da kendini unutup görmediği (kendini sanatına/uğraşısına verdiği) zaman en yüksek işleyiş düzeyine ulaşabilmektedir. Kendini unutmak, duyarlılığı artırırken, kendini vererek yoğunlaşmak sanatsal yaratıcılığ1 artırmaktadır (Frankl, 1999, s. 30; s. 87; Frank1, 2018a, s. 54). Frankl'ın "anlama ulaşma iradesi” olarak ifade ettiği bu davranış sayesinde, bireyin kendini transendense yükselterek, başka bir deyişle kendi-üstünde-dışında artık kendisi olmayan şeye uzandığını belirtmektedir (Frankl, 2014b, s. 30).

Frankl, göz organının kendi kendini görememesi olgusunu şu şekilde açıklamaktadır: Retinanın başında, görme sinirinin başladığı yerde, retinanın kör noktası bulunmaktadır. Tıpkı retina gibi tin de iç bakışa, iç yansımaya karşı kördür diyen Frankl (2014a, s. 26), eski bir Hint deyişini hatırlatmaktadır: "Bir şeyi gören, görülemez; bir şeyi duyan duyulamaz; düşünen, düşünülemez”. Frankl’ın yukarıdaki anlatımda verdiği örneğe benzer şekilde, sanatçının ortaya koyduğu eser "kör nokta"da kaldığı için sanatçı tarafından görülemeyebilmektedir. Zaten ilke olarak sanatçıya, ürününü neden ürettiği, neden sanatsal eserler ortaya koyduğunun sorulmaması gerekmektedir. Sanatçı, kendi eserleri hakkında yorum yapma tasarrufuna elbette ki sahip bulunmaktadır fakat asıl olan, farklı disipliner bakış açılarından, sanatçının eserlerinin yorumlanmasıdır. Bu makalede de psikoloji penceresinden bakmak suretiyle şarkı sözü içerik analizi yapılarak, söz konusu kör noktaya 1şık tutulmaya çalışılmıştır. Bu olguyu Nietzsche (1997, s. 114), şu sözlerle açıklamıştır: "Sanatçı bugüne dek felsefede yoktur. Bu ise gerekli bir boşluktur. Çünkü kendini anlamaya çalışan sanatçı, gücünü tüketebilir; o arkaya bakmamalı; hiçbir şeye bakmamalı, yapıt vermelidir. Bir sanatçı için eleştirme yapmamak bir şereftir, yoksa o ne sanatçı olur ne eleştirmeci, sadece 'çağcıl' olur".

\subsection{Barış Manço ve Sanatı Hakkında Genel Bilgiler}

Müziğe küçük yaşlarda başlayan Manço, çeşitli müzik grupları kurmuş, 200'ün üzerinde şark1 bestelemiş ve sanat yaşamındaki başarıları neticesinde 300'ün üzerinde ödül almıştır. Manço, Türk kültürünü bir bütün olarak ele almış ve tasfiyeci bir anlayıştan ziyade, terkipçi (birleştirici) bir anlayış benimsemiştir (Emre, 2012, s. 640). Türkiye'de toplum ve sanatçı arasındaki diyaloğu en iyi kuran sanatçılardan biri Manço olmuştur. O, toplumun hemen her kesimiyle yani 7'den 77'ye herkesle diyalog kurabilmeyi başarmıştır (Adıgüzel, 2009, s. 85). Manço, bir yandan âşık tarzının müzik eşliğinde şiir söyleme boyutunu, diğer yandan ise hikâye anlatma tekniğini geliştirmeye çalıştığı sanat formunun imkânları içinde eriterek dinleyicisine sunmuştur (Düzgün, 2009, s. 47). Bu sayede Manço, Türkiye’nin yirminci yüzyılda yetiştirdiği en büyük düşünce, kültür sanat, estetik ve aksiyon insanlarından biri olarak ön plana çıkmıştır (Çobanoğlu, 2000, s. 40).

Manço, siyasi bir şarkıcı patenti taşımamış ve siyasal sloganlara rağbet etmemiştir. $O$, felsefesini notalara ve şarkılara güle-oynaya yazan bir Türkiye filozofu olmuştur (Durbaş, 1999, s. VII-VIII). Onun filozof olduğunu anlamak için şarkılarının sözlerini dikkatle okumak yeterli olmaktadır. Şarkıları dikkatle satır satır okunduğunda bunu, bir başka insanın kolay kolay yazamayacağı anlaşılabilmektedir. O, bir bilgenin inceliğinde düşünmüştür (Durbaş, 1999, s. 82). Bir iletişim sanatçısı olan Manço, söylemek istediklerini aktarabilmek için müziği, sahneyi, televizyonu, ellerini, beden dilini, görselliğini kullanmıştır 
(Baydur, 2015, s. 5). Yukarıdaki anlatımlardan da görülebileceği üzere Manço, çok yönlü bir sanatçı olma özelliğine sahip bulunmaktadır. Bu makale, söz konusu farklı özellikler içinden, sanatçının seslendirdiği şarkı sözlerine odaklanılarak kaleme alınmıştır.

\section{3. ÇALIŞMANIN YÖNTEMI}

$\mathrm{Bu}$ makalede, nitel araştırma yaklaşımı benimsenmiş ve araştırma verileri, doküman incelemesi tekniğiyle ele alınmıştır. Makalede, Frankl ekolünün psikolojik bakış açısı çerçevesinde, şarkı sözü içerikleri üzerinde durulmuştur. Bu kapsamda, hem Frankl'ın birincil kaynak eserleri hem de Manço'nun yazılı kaynak haline getirilmiş şarkıları incelenmiştir.

Doküman incelemesi, amaçlanan durum veya olgu hakkında bilgi içeren yazılı kaynakların incelenerek değerlendirilmesini ifade etmektedir. Doküman incelemesi, ilave bir veri kaynağı olarak değil, tek başına bir araştırmanın tüm veri kümesini de oluşturabilmektedir. Böylesi durumlarda, incelenecek dokümanlar arasında örneklem seçimi de söz konusu olabilmektedir (Yıldırım ve Şimşek, 2016, s. 189).

Frankl (2018a, s. 124), bilimsel çalışmalar ile sanatsal çalışmaları kıyasladığı bir anlatımında şunları ifade etmektedir: "Bilimsel bir çalışma yapan psikolog veya psikoterapistin rolü, bir ressamdan çok bir göz uzmanının oynadığı roldür. Ressam bize, dünyayı kendi gördüğü haliyle aktarmaya, göz uzmanı ise dünyayı gerçekte olduğu gibi görmemizi sağlamaya çalışır”. Bu noktada Frankl (2018a, s. 124), bilimsel bir yaklaşım olan kendi ekolünün temel prensiplerini ortaya koyarak, sanatsal bakış açısına özgü nitelikleri sıralamıştır. Buna göre sanatsal yaklaşım, bilimsel anlayıştan farklı olarak şu yönlere sahip bulunabilmektedir:

(1) Öğretici,

(2) Vaaz veren,

(3) Mant1k yürüten,

(4) Ahlaki değer canlandıran.

Manço'nun şarkı sözleri, işte bu dörtlü tipoloji kapsamında incelemeye konu edilerek ayrıma tabi tutulmuştur.

\section{1. Çalışmanın Kısıtları}

Bu makalenin konusu, genelden özele doğru daraltıldığı için başvurulabilecek kaynaklar da kısıtlı hâle gelmiştir. Söz konusu kısıt ise makaledeki, Frankl’ın eserleri eksenli yorum ve değerlendirmelerin ağırlık kazanmasına kaynaklık etmiştir.

Manço, uzun sanat yaşamı süresince seslendirdiği şarkıların sözlerini çoğunlukla kendi yazmıştır. Buna rağmen Adıgüzel (2009, s. 86), Manço’ya şarkı sözü yazarı demenin çok doğru olmayacağını ileri sürmektedir. Bu makalede de şarkı sözlerini kimin yazdığından ziyade, sanatçının seslendirdiği ve büyük ölçüde kendisiyle özdeşleşen şarkı sözü içeriklerine odaklanılmıştır. Hatta biraz daha özele inilerek, Baydur (2015) tarafından yazılı bir kaynak hâline getirilerek toplu biçimde okuyucuyla buluşturulan 80 adet şarkı sözü, inceleme kapsamına alınmıştır (söz konusu çerçeveleme, sanatçının şarkı sözlerine, yazılı kaynak dışındaki internet gibi kaynaklara başvurmaktan kaçınma anlayışı nedeniyle gündeme gelmiştir). 
İncelemeye konu edilen 80 şarkı, sanatçının seslendirdiği tüm eserleri temsil etme, genel hakkında kanaati destekleme ve veri doygunluğunun yeterliliği bakımından kâfi görülmüştür.

Frankl, "Uzmanlar çağında yaşıyoruz ve bunun bazı zararları var. Uzmanı, olgu ağaçları yüzünden hakikat ormanını artık göremeyen biri şeklinde tanımlamak isterim" demektedir (Frankl, 2018b, s. 32). Tipkı uzmanlar gibi yaşam koçluğuna soyunan bazı şarkı sözleri de; olgulardan, inkâr edilemeyecek beylik sözlerden, atasözü ve deyimlerden devşirildiği, salt kafiye olsun diye yazıldığı (bazen buna da özen gösterilmediği) için, olgu ağacı biçiminde birer varlık işlevi görmekte, hakikat ormanına ilişkin içerikleri ise oldukça zayıf kalmaktadır. Bu makalede, gündelik tüketime yönelik pop şarkı sözlerinden özellikle mesafeli durulmaya çalışılmıştır çünkü pop şarkı sözleri üzerine yapılan ön çalışmada, makalenin teorik öngörüsünün işlemediği, bazı sanatçıların şarkı sözlerinin, Frankl'ın dörtlü ayrımına tabi tutulamadığı görülmüştür (Örneğin Mustafa Sandal şarkı sözleri üzerinde yapılan ön çalışmada, şarkı sözlerinin çoğunlukla tekil olgulara yönelik olduğu belirlenmiştir). Yıldırım ve Koç (2011, s. 12), bu durumu, yaşamın ciddi yönden değil, hafif yönden (pop) görmeye bağlı bir olgu olarak açıklamışlardır. Herhangi bir durumdan devşirilmiş verilerde yalnızca analitik kalıba uyan veçhe seçilir diyen Frankl (2018b, s. 100), birçok pop şarkısının, neden belirli bir kalıba konulamayacağına ilişsin dolaylı bir gönderme yapmıştır. Pop şarkılarının tahlil edilebilirlik düzeylerinin düşük olmalarının başlıca nedenleri olarak şu hususlar ön plana çıkmaktadır: (1) Tüketime endeksli olma, (2) nihilizme vardırılan varoluşçu anlayışı benimseme, (3) mesaj kaygısı taşımamama. Sıralanan nedenlere bağlı olarak da meşrebi yeterince ağır olmayan şarkı sözleri kaleme alınmaktadır. Yukarıda açıklanan nedenler ve Manço'nun şarkı sözlerinin, makalenin teorik öngörüsünü destekleyebileceği düşüncesinden hareket edilmiş ve teorik öngörünün işlediği (realize olduğu) görülmüş̧ür. Her ne kadar, Manço’yu Türk pop müziğinin önde gelen temsilcilerinden biri (Düzgün, 2009, s. 45) olarak kabul edenler olsa da ve dahası Manço, pop şarkıları da seslendirmiş olsa da, sanatçı ile ilgili genel bilgilere yer verilen yukarıdaki anlatımlarda da ifade edildiği üzere, çok yönlü bir kişilik olarak Manço'yu salt bir popçu olarak ifade etmek, onun sanatını eksik değerlendirmek anlamına gelmektedir. Zira sanat ile ilişkili olarak yapılan çalı̧̧malarda kısa yoldan hüküm verme çabasına girişerek indirgemeci tavır takınmak, sanatın özüne aykırı düşen bir yaklaşımı ifade etmektedir.

\subsection{Verilerin İncelenmesi}

Makale kapsamında yapılan doküman incelemesi (dokümanda yer verilen şarkıların içerik analizi), alanında uzman üçüncü bir kişiye de incelettirilerek ayrıntılı görüş istenmiştir. Bağımsız olarak yürütülen incelemelerde mutabakat ve görüş ayrllıklarının olduğu hususlar tespit edilmiştir. Uzman görüşünün, araştırmacının kodlandırmasından farklı olarak belirlediği görüşler tekrar değerlendirmeye alınmıştır. Son olarak ise kodlamaların tamamına yönelik görüş birliği sağlanmıştır. Bulguların yorumlanması kısmında bulgular, dört tema ekseninde yapılandırılmış, literatürle karşılaştırılmış ve bazı şarkı sözlerinden doğrudan alıntılar yapılarak değerlendirmeye tabi tutulmuştur.

\section{BULGULAR: BARIŞ MANÇO ŞARKILARININ VIKTOR FRANKL EKOLÜ AÇISINDAN DEĞERLENDİRILMESI}

Her kültürün kendine özgü bir damak tadı, sanatlarda ifade edilen ve özel anlamlar taşıyan renk, şekil ve müzik anlayışı bulunmaktadır (Schein, 2004, s. 110). Türk kültürünün de kendine özgü müzik 
anlayışı bulunmaktadır. Uzun bir sanat geçmişine sahip olan Manço, Türk müzik kültürde kendine has bir yer edinmiştir.

Tablo 1, Baydur (2015) tarafından yazılı hâle getirilerek, şarkı adlarına göre alfabetik sıraya konulan Manço'nun 80 şarkı sözünden oluşturulmuştur. Söz konusu 80 şarkı sözü, Frankl'ın dörtlü tipolojisi kapsamında değerlendirilmiştir. Tablo 1'deki dağılım incelendiğinde “Öğretici” içerikli şark1 sözünün toplam 33 olduğu görülmektedir. "Vaaz veren” içerikli şarkı sözleri sayısının toplamı ise 21 'dir. "Mantık yürüten" içerikli şarkı sözlerinin toplam sayısına bakıldığında, bu sayının 57 olduğu görülebilmektedir. Son olarak “Ahlaki değer canlandıran” şarkı sözü içeriklerinin, toplamda 35 olduğu görülmektedir. $\mathrm{Bu}$ dört rakam toplandığında ise $(33+21+57+35) 146$ rakamına ulaş1lmaktadır. 80 şark1 sözünün, Tablo 1'de 146 adet yer almasının nedeni, bazı şarkı sözlerinin 1'den fazla içeriğe sahip olması münasebetiyle, tablonun 1'den fazla satırında yer verilmiş olmasından (şarkı sözlerine tabloda mükerrer olarak yer verilmesinden) kaynaklanmaktadır.

Tablo 1. Barış Manço'nun Şarkı Sözü İçeriklerinin, Frankl’ın Bakış Açısı Kapsamındaki Dağılımı

\begin{tabular}{|c|c|}
\hline Şarkı Sözü İçeriği & Şarkı İsmi \\
\hline Öğretici & $\begin{array}{l}\text { Adem Oğlu Kızgın Fırın Havva Kızı Mercimek, Ahmet Bey’in Ceketi, Aman Yavaş } \\
\text { Aheste, Anahtar, Arkadaşım Eşek, Ayı, Benden Öte Benden Ziyade, Binboğanın Kızı, } \\
\text { Bugün Bayram, Cacık, Delikanlı Gibi, Dıral Dedenin Düdüğü, Dört Kapı, Eski Bir } \\
\text { Fincan, Gibi Gibi, Gönül Ferman Dinlemiyor, Güle Güle Oğlum, Günaydın Çocuklar, } \\
\text { Halil İbrahim Sofrası, Hemşerim Memleket Nire?, Kazma, Kezban, Lahburger, } \\
\text { Müsaadenizle Çocuklar, Nane Limon Kabuğu, Nick The Chopper, Osman, Ömrümün } \\
\text { Sonbaharında, Sarı Çizmeli Mehmet Ağa, Seher Vakti, Süleyman, Süper Babaanne, } \\
\text { Yol }\end{array}$ \\
\hline Vaaz Veren & $\begin{array}{l}\text { Adem Oğlu Kızgın Fırın Havva Kızı Mercimek, Ahmet Bey'in Ceketi, Benden Öte } \\
\text { Benden Ziyade, Binboğanın Kızı, Can Bedenden Çıkmayınca, Dıral Dedenin Düdüğü, } \\
\text { Dört Kapı, Eski Bir Fincan, Gönül Ferman Dinlemiyor, Güle Güle Oğlum, Halil } \\
\text { İbrahim Sofrası, Hemşerim Memleket Nire?, Kazma, Müsaadenizle Çocuklar, Nane } \\
\text { Limon Kabuğu, Osman, Ölüm Allah'ın Emri, Ömrümün Sonbaharında, Sarı Çizmeli } \\
\text { Mehmet Ağa, Süleyman, Yol }\end{array}$ \\
\hline Mantık Yürüten & $\begin{array}{l}\text { Acıh da Bağa Vir, Adem Oğlu Kızgın Fırın Havva Kızı Mercimek, Ahmet Bey’in } \\
\text { Ceketi, Al Beni, Ali Yazar Veli Bozar, Aman Yavaş Aheste, Anahtar, Anlıyorsun } \\
\text { Değil mi?, Arkadaşım Eşek, Ayı, Bahçede Hanımeli, Bal Sultan, Benden Öte Benden } \\
\text { Ziyade, Beyhude Geçti Yıllar, Binboğanın Kızı, Cacık, Can Bedenden Çıkmayınca, } \\
\text { Ce Sera Le Temps, Dağlar Dağlar, Delikanlı Gibi, Dıral Dedenin Düdüğü, Domates } \\
\text { Biber Patlıcan, Dönence, Dört Kapı, Düriye, Eğri Büğrü, Gibi Gibi, Gönül Ferman } \\
\text { Dinlemiyor, Gül Bebeğim, Günaydın Çocuklar, Hal Hal, Halil İbrahim Sofrası, Hayır, } \\
\text { Hemşerim Memleket Nire?, İşte Hendek İşte Deve, Kalpler Beraber, Kara Sevda, } \\
\text { Kazma, Kezban, Kol Düğmeleri, Lahburger, Mahkum, Müsaadenizle Çocuklar, Nane } \\
\text { Limon Kabuğu, Ne Köy Olur Ne Kasaba, Ne Ola Yar Ola, Osman, Ölüm Allah'ın } \\
\text { Emri, Sarı Çizmeli Mehmet Ağa, Seher Vakti, Söyle Zalim Sultan, Süleyman, Süper } \\
\text { Babaanne, Unutamadım, Yine Yol Göründü Gurbete, Yol, Zehra }\end{array}$ \\
\hline Ahlaki Değer Canlandıran & $\begin{array}{l}\text { Acıh da Bağa Vir, Adem Oğlu Kızgın Fırın Havva Kızı Mercimek, Ahmet Bey’in } \\
\text { Ceketi, Ali Yazar Veli Bozar, Aman Yavaş Aheste, Arkadaşım Eşek, Ayı, Bal Böceği, } \\
\text { Benden Öte Benden Ziyade, Bir Selam Sana Gönül Dağlarından, Delikanlı Gibi, Dıral } \\
\text { Dedenin Düdüğü, Dört Kapı, Eğri Büğrü, Gül Bebeğim, Günaydın Çocuklar, Halil } \\
\text { İbrahim Sofrası, Hatırlasana, Hayır, Hemşerim Memleket Nire?, Kazma, Kezban, } \\
\text { Lahburger, Mahkum, Müsaadenizle Çocuklar, Nane Limon Kabuğu, Nick The } \\
\text { Chopper, Osman, Ömrümün Sonbaharında, Sarı Çizmeli Mehmet Ağa, Süleyman, } \\
\text { Süper Babaanne, Yol, Yolla Yârim Tez Yolla, Zehra }\end{array}$ \\
\hline
\end{tabular}

Baydur'un (2015) kitabında yer aldığı halde, Tablo 1'de yer verilmeyen toplam 14 (Alla Beni Pulla Beni, Allah’ım Güç Ver Bana, Aynalı Kemer, Ben Bilirim, Elveda Ölüm, En Büyük Mehmet Bizim Mehmet, Ey Koca Topçu (Genç Osman), Gülpembe, Lambaya Püf De, Little Darling, Nazar Eyle, S.O.S Aman Hocam, Sahilde, Sakız Hanım Mahur Bey) adet şarkı bulunmaktadır. Bu 14 şarkının genel anlamda 
içerikleri incelendiğinde, ortak yön olarak duygusal zeminde hissedilenlerin kaleme alındığı görülebilmektedir. Bu şarkılarda genel olarak sevgilinin özelliklerine ilişkin tasvirler, güzellemeler, yergiler, sitemler, sevgiliye karşı hissedilen olumlu/olumsuz duygular dile getirilmektedir. Yine bu şarkılarda genel anlamda olgular ve bu olgulara ilişkin çeşitli yargılar dile getirilmektedir (söz konusu yargılara, Frankl'ın dörtlü ayrımı kapsamı dışında varılmaktadır). Bu tür şarkı sözlerine örnek teşkil etmesi ve diğer şarkı sözlerine kıyasla daha kısa olması bakımından "Elveda Ölüm” adlı şarkının sözleri aşağıya aktarılmıştır. "Elveda Ölüm” şarkı sözlerinin, birtakım genel olguları dile getirmekte ve Frankl'ın dörtlü ayrımına tabi tutulmasının olanaksız olduğu, aşağıdaki aktarımda da açıkça görülebilmektedir:

\section{Elveda Ölüm}

Çoktan uçmuş güvercin, tahta masam devrilmiş

Can dostum Çomar uykuda

Tatlı komşu Ayşe Teyze, emekli Salih Öğretmen

Hepinize elveda

Dostlar elveda

Gözlerim kurşun gibi ă̆ır ă̆ır kapandı bu gece

Elveda (Baydur, 2015, s. 76).

\section{1. Şarkı Sözü İçeriklerinin “Öğretici” Yönüne İlişkin Bulgular}

Frankl'a göre, bedensel (somatic) ve psişik fenomenlere karşı tavır takınmak, bunların seviyesinin aşılması ve yeni bir boyutun açılması demektir. Bu yeni boyut, biyolojik ve psikolojik boyutla karşıtlık içindeki eşsiz insani fenomenlerin yer aldığı boyuttur (Frankl, 2018b, s. 30). Frankl, şartlanma süreçlerine bağlı kalarak insan davranışlarını analiz etmeye çalışan davranışçı psikoloji yaklaşımını her fırsatta eleştirmektedir. Frankl'a göre insan davranışları, İvan Pavlov'un köpekler üzerinde yaptığı ve insanlara da atfedilen şartlanma süreçlerine bağlı deneylerdeki davranışsal kalıpların ötesine geçmektedir. Özellikle insanın sanatsal yönü, indirgemeci (redüksiyonist) şartlanma süreçlerinin çok ötesine geçmektedir. Frank1, doğal olarak öğrenme/öğretme süreçlerine yönelik davranışçı psikolojinin yaklaşımına da şiddetle karşı çıkmaktadır.

Hayatın içinden gelen müzik, belirli değer ve inançların öğrenilmesi (dolayısıyla da öğretilmesi) bakımından oldukça etkili bir niteliğe sahip bulunmaktadır (Bilgin ve Sarıcı, 2018). Bu etki, Frankl'ın tipolojisindeki "öğretici olma” unsurunu vurgulamaktadır. Söyleme dayalı sanat dalları, doğal olarak yazınsal unsurları bünyesinde barındırmaktadır. Müzik sanatı, özellikle şarkıların sözlerle ifade edildiği “güfte” unsurunu kapsamaktadır. Birçok söylemsel ve yazınsal eylem, Frankl tarafından ifade edilen didaktik kaygıları (öğretici olma) içermektedir. Söz yazarı, bireyselliğin ötesine geçerek geniş kitlelere ulaşma olanağına kavuşabilmekte, bunu da müzik aracılığıyla gerçekleştirebilmektedir.

Manço, şarkılarının genelinde, yukarıdaki anlatımda ifade edilen didaktik olma kaygısı göze çarpmaktadır. Manço'nun öğretici olma misyonunu üstlenme konusundaki istekliliği ve bu konudaki başarısı, Baydur (2015,s. 3) tarafından şu sözlerle ifade edilmektedir: “Atatürk’ümüzden sonra ülkemizin ikinci başöğretmeni”. Ruhat Mengi, Manço’nun öğretici yönünü şu sözlerle dile getirmektedir (Durbaş, 
1999, s. 84): “Aceleciydi, bütün bilgisini, birikimini Türkiye’ye aktarması gerekiyormuş bir an önce gibi, hızla konuşup j-hızla anlatıyordu. Sevgiyi anlatıyordu, çocuklara, insanlara mesajlar veriyordu”.

Manço'nun çocuklara yönelik şarkıları, öğretici pek çok unsuru barındırmaktadır. Aşağıdaki şarkı nakaratının sözlerinde de öğreticilik unsuru ön plana çıkmaktadır:

\title{
Bugün Bayram
}

\author{
Bugün bayram erken kalkın çocuklar \\ Giyelim en güzel giysileri \\ Ellimizde taze kır çiçekleri \\ Üzmeyelim bugün annemizi...
}

\section{2. Şarkı Sözü İçeriklerinin "Vaaz Veren” Yönüne İlişkin Bulgular}

Frankl (2018b, s. 16; s. 145-171), genel olarak psikolojiyi de, psikoloji alanına kazandırmış olduğu bakış açısını da "tıbbi vaizlik" olarak nitelendirmektedir. Frankl (2018b, s. 171), söz konusu nitelemesinde şu sözlere yer vermektedir: "Tıbbi vaizlik hekimin meşru görevidir. Elbette onsuz yapabiliriz ve hekim olmayı da sürdürürüz ancak -Paul Dubois'in nükteli ifadesini anarsak- bu durumda fark etmemiz gerekir ki bizi veterinerden ayıran tek şey baktığımız hastalardır”. Frankl’ın bakış açısıyla ifade edildiğinde, nasihat etme, vaaz verme eğilimleri bulunan şarkı sözlerini de "sanatsal vaizlik" olarak nitelendirebilmek olası gözükmektedir. Bu temel mantıktan hareket edildiğinde, Manço'nun şarkı sözlerinde sanatsal vaizlik unsurunun yer almakta olduğunu ifade etmek mümkün olabilmektedir.

“Vaaz” kelimesi, Türk Dil Kurumu Yayınları Türkçe Sözlük’te (2011, s. 2463) öğüt niteliği taşıyan dini konuşma olarak tanımlanmaktadır. Dolayısıyla vaaz verme, öncelikli olarak din ile ilişkili öğütleri ön plana çıkarmaktadır. Vaaz verme davranışı, genellikle dini içerikli anlatımlarda veya bireysel gelişim evreleri bakımından yetişkinlik dönemini geride bırakarak atalık/yaşlılık dönemine girmiş bulunan insanlarda sıklıkla gözlemlenmektedir. Vaaz verme, bir önceki anlatım başlı̆̆ındaki öğretici olma durumu ile benzer yönler taşımasına karşılık, din ve öğüt verme konularında çok daha belirgin bir niteliğe bürünmektedir. Aşağıdaki aktarımlar, Manço’nun şarkı sözlerindeki vaaz verme yönüne örnek teşkil etmektedir:

\section{Ahmet Bey'in Ceketi}

Tanrı bütün kullarına rızkını dağıtırken

Kimi sırtüstü yatar kimi boşta gezerken

Kul Ahmet erken kalkar haydi ya nasip derdi

Kimseler anlamazd ya nasip ne demekti...

\section{Dıral Dedenin Düdüğ̈̈̈}

Hele destur maşallah bu ne bolluk böyle

Hele destur helalinden kazandiysan söyle

Hele destur gözümüz yok Allah daha çok versin

Ama paylaş, gel beni dinle, paylaşırsan sevaba girersin...

Hele destur maşallah bu ne kudret böyle 
Hele destur zayıflarl ezmedin mi söyle

Hele destur gözümüz yok Allah daha iyi etsin

Ama paylaş, gel beni dinle, ardindan herkes dua etsin...

Yukarıda aktarılan Dıral Dedenin Düdüğ̈̈ şark1 sözleri; öğretici olma, vaaz verme, mantık yürütme ve ahlaki değer canlandırma niteliklerinin hepsine sahip bulunmaktadır. Bu nitelikler, şarkının tamamına dağılmış bir biçimde yer almakta; maşallah, helal, Allah, sevap ve dua gibi kavramlar üzerinden vaaz niteliğinde öğütler içermektedir. Şarkının yukarıda aktarılan bölümlerinde helal-haram, kudretli-zayıf, ezen-ezilen, paylaşan-paylaşmayan gibi yol ayrımları bakımından ahlaki değer canlandırma yapılmaktadır. "Bu ne bolluk böyle" şeklinde sorgulayıc bir söylemde bulunulmakta, bolluğa işaret edilen unsurların (mal varlı̆̆ı, güç vb.), helal dairesinden veya doğruluktan taviz verilmediği (dolayısıyla da helal-haram, doğruyanlış gibi ahlaki yol ayrımlarında olumsuzluğa meyledilmediği) sürece, kolaylıkla elde edilemeyeceğine yönelik olarak mantıki çıkarımlar (mantık yürütmeler) yapılmaktadır.

\section{3. Şarkı Sözü İçeriklerinin “Mantık Yürüten” Yönüne İlişkin Bulgular}

Mantık, bir şeyin başka bir şeyden çıktığı ya da başka bir şeyin sonucu olduğu bağlantıları inceleyen formel disiplindir (Cevizci, 2000, s. 618). Mantık kelimesi, Arapça "nutk" (nutuk) kelimesinden gelmektedir. Yunanca "logos" kelimesi, Batı dillerindeki mantık kelimesine kaynaklık etmektedir. "Logos" ve "nutk"; akıl, yasa, doğru söz, düzen, ilke ve düşünme anlamlarına gelmektedir. Dolayısıyla mantık yürütme, doğru ve düzgün düşünme (Çüçen, 2006, s. 15) ve çıkarsama yapmayı ifade etmektedir. Manço şarkıları arasında mantık yürüten içeriğe sahip bulunanlara örnek olması bakımından aşağıdaki aktarmalar dikkat çekici nitelikler taşımaktadır.

\section{Düriye (Şarkı nakaratları)}

$\cdots$

Meyve veren ağaç dallarını eğer mi?

Yer düşen meyveyi hiç toplamaya değer mi?...

$\cdots$

Altın çöpe düssse değerin kaybeder mi?

Tenekeyi parlatsan hiç çeyrek altın eder mi?...

Dama çıkmak isteyen merdivenden iner mi?

Insan attan inip hiç eşeğe biner mi?...

\section{Kazma}

-..

Komşunun tavuğu komşuya kaz görünür dersen

Kaz gelen yerden tavuğu esirgemezsen

Bu kafayla bir baltaya sap olamazsin ama

Gün gelir sapın ucuna olursun kazma

Düriye ve Kazma isimli şarkıların yukarıda aktarılan nakaratlarının, mantık yürütme (mantıki çıkarımlarda bulunma) unsurunu ortaya koyduğu, açık bir şekilde görülebilmektedir. 


\section{4. Şarkı Sözü İçeriklerinin “Ahlaki Değer Canlandıran” Yönüne İlişkin Bulgular}

En genel anlamda iyi ile kötüyü belirlemeye yönelmiş olan ahlak, bütün insan topluluklarının tutum, inanç, töre ve geleneklerine bağlı olarak tarihin ilk çağlarından itibaren var olmuştur (Bayrak, 2001, s. 1). Genel geçer değerler ve ahlaki prensipler, insanlar için uyulması gereken dayanakları belirlemiş̧tir (Frankl, 2014a, s. 86). "Benim yaklaşımım uygulamada ahlakçı mıdır? Basit bir nedenden dolayı değildir, çünkü anlam reçeteyle verilemez" diyen Frankl (2014a, s. 80), bu sözleriyle aslında (sanata ilişkin kişisel bakış açısından farklı olarak) "bilime bakış açısının" neden ahlaki değer canlandırmadan uzak (ahlak dışı: immoral) olduğunu ifade etmektedir. Benzer bir örnek olarak iktisat biliminin "ahlak dışı: la ahlaki” bir bilim dalı olmasını gösterebilmek mümkündür. Zira iktisat, olguları salt ahlak penceresinden değil, kendi rasyonel ve objektif kriterleri çerçevesinde ele almaktadır. Örneğin ekmek gibi kutsal addedilen bir ürünü üreten iktisadi kuruluşu da içki gibi olumsuz addedilen ürünü üreten kuruluşu da ahlaki anlamda yansız olan iktisadi bakış açısıyla ele almaktadır.

Manço, Türk insanının geçmişini olabildiğince geniş kavrayıp, onu genç kuşaklara aktarmayı kendisine görev bilmiştir. Manço, ülke insanına özgü ama sanki kaybolmuş gibi olan bazı hasletlerin altını ısrarla çizmekten kaçınmamıştır (Durbaş, 1999, s. 14). Manço, şarkılarında divan edebiyatı, dini tasavvufi halkı edebiyatı, âşı edebiyatı unsurlarına yer vermiştir (Emre, 2012, s. 640).

Yukarıdaki anlatımlar ve şarkı sözü içeriklerinden de anlaşılabileceği üzere Manço, şarkılarında iyi-kötü, doğru-yanlış, güzel-çirkin gibi ikili yol ayrımlarını içeren ahlaki değer temelli yaklaşımlarını şarkılarına sıklıkla yansıtmıştır. Şarkı sözlerine yansıyan "ahlaki değer canlandırma” unsura ilişkin örnekler aşağıda aktarılmıştır.

\section{Bal Böceği}

Seyyah oldum dolaştım şu âlemi, ah güzelim

Senin gibi bir vefastz görmedim ben

Hayırsızl, kitapsızl, zalimi bal böceğim

Senin gibi bir insafslz görmedim ben...

Bu şarkıda, vefalı-vefasız, hayırlı-hayırsız, kitap ehli - kitapsız, zalim-zalim olmayan (haksızlık eden-etmeye), insaflı-insafsız gibi ikili karşıtlık içinde yer alan kavramlar üzerinden ahlaki değer canlandırma yapılmaktadır.

\section{Delikanlı Gibi}

$\cdots$

\section{Beni kovsalar dokuz köyden}

Doğruyu hep söylerim ben

Ölürüm de dönmem sözümden delikanll gibi...

Yukarıdaki şarkı sözlerinde de doğru-yanlış, sözünden dönmemek-dönmek gibi ahlaki değerler dile getirilmektedir. Şarkının adında ve şarkı sözlerinde de sıklıkla geçen "delikanlı" kelimesinin de sözünün eri, dürüst namuslu kimse (www.tdk.gov.tr) anlamına geldiği düşünüldüğünde, ahlaki değer canlandırma unsurunun, şarkıda belirginleşmekte olduğu görülebilmektedir. 


\section{SONUÇ VE TARTIŞMA}

Sanatın her türünün, hak ettiği değeri görmesi gerekmektedir. Frankl, birçok yaşamsal konuda olduğu gibi, sanatsal uğraşılar konusunda da yeterli duyarlılı̆̆ı göstermeyen kişileri eleştirmektedir. Frankl, insanların yüzeysellikleri ve duygusuzlukları, yaşamsal ve sanatsal uğraşıları sadece omuz silkmeyle ve sıradan ifadelerle karşılamalarını kabul edilemez bulmaktadır (Frankl, 2018a, s. 107).

Frankl'ın ben-sen ilişkisi yaklaşımını, yazar (ben) ile okuyucu (sen) arasındaki etkileşime uyarlayabilmek mümkün gözükmektedir. Frankl'a göre, “ben ve sen”in; kendilerini, kendileri dışındaki bir anlama gönderme yapabilme adına aşmaları gerekmektedir (Frankl, 2018b, s. 19). Bir diğer söyleyişle, ben ile sen'in asgari bir müşterekte buluşabilmeleri, belirli (aşkın) bir anlama gönderme yapabilmeleri için kendilerini aşmaları icap etmektedir. Bunu başaramadıkları sürece, ben ile sen arasındaki her türlü diyalog çabası boşa çıkabilmektedir. Başarabildikleri takdirde ise karşılaşmanın tarafları, birbirlerini içtenlikle dinler hâle gelmekte ve ontolojik sağırlıklarından kurtulabilmektedirler (Frankl, 2018b, s. 19). Frankl'ın psikoloji yaklaşımında yer alan ve dörtlü ayrıma dayalı bulunan tipolojisinin, müzik alanına uyarlanması, bu alanda ilk defa gerçekleştirilmiş özgün bir yaklaşım olma niteliği taşımaktadır. Söz konusu yaklaşımı benimseyen bu makalenin yazarı (ben); okuyucu (sen) ile arasında, kendileri dışındaki bir anlam olarak Frankl'ın dörtlü ayrıma dayalı tipolojisindeki “anlam”a gönderme yapmayı, bu sayede de, taraflar arasında sağlıklı/sağlam bir diyaloğun oluşmasını ve ontolojik körlük/sağırlıklardan belirli ölçülerde kurtulabilmeyi amaçlamaktadır.

Psikolojik faktörler; hem sanatsal yönelimi tetikleyen/başlatan bir unsur olarak, hem de sanatsal uğraşıyı gerçekleştirme sürecinde bireyi yönlendiren bir güdü olması bakımından etkili bir rol üstlenmektedir. Frankl, sanatsal aktiviteler de dâhil olmak üzere bütün yaşamsal aktiviteleri, kendi özgün yaklaşımı çerçevesinde izah etmeye çalışmıştır. Bu makalede, Frankl'ın söz konusu yaklaşımını ele almak suretiyle, müzik bilimleri literatüründe henüz tartışılmamış olan yönlerini ortaya koyarak okuyucunun dikkatini, psikoloji ekolleri üzerine çekebilmek hedeflenmiştir. Makalede, mümkün olduğu ölçüde Frankl'ın bakış açısı, yine onun tarafından kavramlaştırılan özgün terimler aracılığıyla ele alınmaya çalışılmıştır. Gelecekte benzer türden yapılacak çalışmalarda konunun; anlam istenci, varoluşsal boşluk, minyatür büyüklük yanılsaması, nesnel/dışsal başarı, bilinçsiz aşağılama ihtiyacı, yapay iyimserlik gibi Frankl tarafından literatüre kazandırılmış kavramlar çerçevesinde de tartışılabilmesi olası gözükmektedir.

$\mathrm{Bu}$ makalede, Frankl'ın sanatsal çalışmalara yönelik bakış açısı ele alınmıştır. Frankl'ın sanat/müzik alanına yönelik yaklaşımları üzerinde durulmuştur. Müziğin ayrılmaz bir bileşen olan şarkı sözü içeriklerinin, psikolojik yönü üzerinde durularak bu içereik, Frankl ekolü ekseninde incelenmiştir. İnceleme kapsamda, Manço'nun şarkı sözleri, Frankl'ın birincil kaynak eserleri doğrultusunda nitel araştırmaya tabi tutulmuştur. Araştırma yöntemi olarak "doküman incelemesi” tekniğinin kullanıldığı incelemede, Frankl'ın bakış açısı doğrultusunda açıklama ve değerlendirmelerde bulunulmuştur. Makalede ulaşılan genel sonuca göre, sanatsal çalışmaları, bilimsel çalışmalardan ayrı kılan dört temel bileşenin varlığını ileri süren Frankl'ın bu yaklaşımının, Manço tarafından seslendirilen şarkılar kapsamında anlamlı bir şekilde desteklenmekte olduğu belirlenmiştir. Keşifsel bir çalışma olarak bu makale, benzer bir anlayış çerçevesinde yürütülecek olan gelecek çalışmalar için katkı sunabilecek tartışma ve değerlendirmeleri okuyucunun dikkatine sunmuştur. 
Makalenin “Giriş” bölümünde, sanata ve müzik sanatına olumlu ve olumsuz yaklaşan filozofların birincil kaynak eserleri sıralanmıştır. Bu aktarım bile tek başına, sanatsal çalışmalara felsefi bakış açısını ve Yenişehirlioğlu (1982, s. 129-134) tarafından izah edilen sanat-felsefe ilişkisini/etkileşimini, daha ileri düzeyde ele almaya dönük çalışmalar yapılmasını teşvik edici bir nitelik taşımaktadır. Buna karşılık, okuyucunun, felsefi eserler üzerinde yapacağı okumalara ihtiyat payıyla yaklaşması zorunluluğunun altını çizmek gerekmektedir çünkü örneğin Platon, Devlet adlı kitabının ikinci bölümünde müzik sanatını olumlu olarak değerlendirmekte iken, aynı kitabın onuncu bölümünde (Platon, 2010, s. 359-363) olumsuz olarak değerlendirmektedir. Bir diğer örneği, sinizm/kinizm akımı üzerinden verebilmek mümkündür. Bilindiği üzere sinizm, Sokrates sonrası ortaya çıkmış başlıca akımlardan biri olmuştur. Bu akım, yerini zamanla stoacı anlayışa bırakmıştır. Sinizmin kurucusu olan Sinoplu Diyojen başta olmak üzere, sinik ve stoacı filozoflar genellikle sanat karşıtlığıyla ön plana çıkmış olmalarına karşılık, yine makalenin "Girişs" bölümünde de görülebileceği üzere, stoacı düşünür olan Seneca'nın eserlerinde sanata karşı olumlu yaklaşımlara rastlamak mümkün olabilmektedir.

\section{KAYNAKÇA}

Abbott E. A. (2016). Düzdünya. (Ş. Çetin Çev.) İstanbul: Sola.

Adıgüzel, M. S. (2009). Vefatının 10. Yılı Dolayısıyla Karınca Dostu Bir Ağustos Böceği: Barış Manço (1943-1999), Abant İzzet Baysal Üniversitesi Dergisi, 9(2), 83-91.

Adler, A. (1996). Psikolojik Aktivite. (B. Çorakçı, Çev.). İstanbul: Say.

Adler, A. (2011). Çocukta yaşamsal sorunlar. (İ. Kırımlı, Çev). Ankara: Alter.

Adler, A. (2012a). Yaşamın anlam ve amacı. (K. Şipal, Çev.). İstanbul: Say.

Adler, A. (2012b). Insanı tanıma sanatı. (K. Şipal, Çev.). İstanbul: Say.

Akan, N. (2012). Platon'da müzik, İstanbul: Bağlam.

Akkılıç, Cem (Haz.) (1995). Led zeppelin ve tüm şarkı sözleri, İstanbul: İmge Stüdyo.

Aristoteles, (2008). Politika. (M. Tunçay, Çev.). İstanbul: Remzi.

Aristoteles, (2017). Nikomakhos'a etik. (F. Akderin, Çev.). İstanbul: Say.

Baydur, Y. Dağhan (2015). Sözler barış manço 80 müzik sözü 80 sanat gözü, İstanbul: A4 Ofset Matbaacilik.

Bilgin O. ve Sarıcı H. (2018). Türk Arabesk Müziğinin Varoluşçu Terapi Açısından İncelenmesi, Ĕgitim ve Öğretim Araştırmaları Dergisi, 7(3).

Boethius, (2006). Felsefenin tesellisi. (Ç. Dürüşken, Çev.). İstanbul: Kabalc1.

Campanella, T. (2011). Güneş ülkesi. (S. Bağdatlı, Çev.). İstanbul: Say.

Cevizci, A. (2000). Felsefe sözlüğ̈̈. İstanbul: Paradigma Yayınları.

Çobanoğlu, Ö. (2000). Barış Manço Araştırmalarının Önemi ve Yöntemi Üzerine Tespitler, Milli Folklor Dergisi, S: 46, 40-47.

Çüçen, A. K. (2006). Mantık, Bursa: Asa.

Diderot D. ve D’alembert J.R. (2005). Ansiklopedi Bilimler, Sanatlar ve Zanaatlar Açıklamalı Sözlüğ̈̈̈. (S. Hilav, Çev.). İstanbul: Yapı Kredi.

Dikici, R. (2005). Cumhuriyetin diva'sı müzeyyen senar, İstanbul: Remzi. 
Dikici, R. (2017). Müzeyyen senar efsanesi, İstanbul: Remzi.

Durbaş, Refik (Haz.) (1999). Ali kırca ile siyaset meydanı, barış manço ’ya özlem, İstanbul: Sabah Kitapları.

Düzgün, D. (2009). Âşıklık Geleneğinin Değişim ve Dönüşüm Sürecinde Barış Manço Olgusu, Milli Folklor Dergisi, 21(84), 42-50.

Emre, H. (2012). Türk Kültürüne Ait Destan, Efsane ve Anlatılarda Sıkça Geçen Formel Sayıların Barış Manço Şarkılarındaki Yeri, Batman Üniversitesi Yaşam Bilimleri Dergisi, 1(1), 639-647.

Erasmus, D. (2000). Bir hıristiyan prensin ĕgitimi. (T. Göbekçin, Çev.). Ankara: Öteki.

Farabi, (1955). İlimlerin sayımı. (A. Ateş, Çev.). İstanbul: Maarif Basımevi.

Frankl, V. E. (1999). Duyulmayan anlam çı̆̆lı̆̆ı psikoterapi ve hümanizm. (S. Budak, Çev.). Ankara: Öteki.

Frankl, V. E. (2014a). Psikoterapi ve din bilinçdışındaki tanrı. (Z. Taşkın, Çev.). İstanbul: Say.

Frankl, V. E. (2014b). Hayatın anlamı ve psikoterapi, (V. Atayman, Çev.). İstanbul: Say.

Frankl, V. E. (2018a). Insanın anlam arayışı (Çev. Selçuk Budak), İstanbul: Okuyan Us.

Frankl, V. E. (2018b). Anlam istenci logoterapinin temelleri ve logoterapi uygulamalarl. (M. Yalçınkaya, Çev.). Ankara: Öteki.

Freud, S. (2011). Uygarlı̆̆ın huzursuzluğu, (H. Barışcan, Çev.). İstanbul: Metis.

Gençtanırım D. ve Voltan Acar N. (2007). Akılcı-Duygusal Yaklaşım ve Sezen Aksu Şarkıları, Eğitim ve Bilim Dergisi, 32 (143), 27-40.

Güntekin, R. N. (1976). Reşat nuri güntekin'in tiyatro ile ilgili makaleleri, (Haz. Kemal Yavuz), İstanbul: Milli Eğitim Basımevi.

Hesse, H. (1994). Entelektüelin Kütüphanesi, İstanbul: Era.

Hobbes, T. (2014). Yurttaşlık felsefesinin temelleri. (C. D. Zarakolu, Çev.). İstanbul: Belge.

Hobbes, T. (2017). Leviathan. (S. Lim, Çev.). İstanbul: Yapı Kredi.

Işık C. ve Işık N. E. (2013). Müslüm gürses ve arabesk, İstanbul: Ferfir.

Kınalızade Ali Efendi, (2011). Ruhun üç kuvveti, Haz. Ali Faruk, İstanbul: Hayat.

Montaigne, (2011). Denemeler. (Y. Şahin, Çev.). İstanbul: Sis.

More, T. (2011). Utopia. (S. Eyüboğlu, V. Günyol ve M. Urgani, Çev.). İstanbul: İş Bankası Kültür.

Nietzsche F. W. (1997). Seçilmiş düşünceler (demeneler) (S. Tiryakioğlu, Çev.). İstanbul: Asos. Nietzsche F. W. (2014). Şen bilim. (E. Aktan, Çev.). Ankara: Alter.

Nizami, (2009). Mahzen-i Esrar, (Haz. Sadık Yalsızuçanlar). İstanbul: Lacivert.

Platon, (2010). Devlet. (S. Berker, Çev.). İstanbul: Athena.

Plutarkhos, (2002). Lykurgos 'un hayatı. (S. Eyüboğlu ve V. Günyol, Çev.). İstanbul: Türkiye İş Bankası Kültür Yayınları.

Rousseau, J.J. (1997). İlimler ve sanatlar hakkında nutuk. (S. Eyüboğlu, Çev.). İstanbul: Milli Eğitim Basımevi. 
Schein, E. (1990). Organizational Culture. American Psychologist. C.45: 109-119. Schein, Edgar. 2004. Organizational Culture and Leadership. 3. bs. San Francisco: Jossey-Bass Publishers.

Schopenhauer, A. (2008). Üniversiteler ve felsefe, (A. Aydoğan, Çev.). İstanbul: Say.

Seneca, (2017). Bilgenin sarsılmazlı̆̆l üzerine inziva üzerine. (C. C. Çevik, Çev.). İstanbul: Türkiye İş Bankası Kültür.

Şanlıdağ, H. Ş. (Haz.) (2016). "Ses'in dili”: tolga çandar, Muğla: Milas Belediyesi Yayınları. Şirazi, S. (2004). Bostan ve gülistan \& allame zemahşeri altın küpeler, İstanbul: Bedir.

Tusi, N. (2007). Ahlak-ı Nasıri, (A. Gafarov ve Z. Şükürov, Çev.). İstanbul: Litera.

Türkçe Sözlük, (2011). Ankara: Türk Dil Kurumu Yayınları.

Uygun, H. (2000). Metallica tüm şarkı sözleri, İstanbul: İmge Stüdyo.

Yalçın, İ. ve Voltan Acar N. (2006). Candan Erçetin'in Seslendirdiği Şarkıların Gestalt Terapi Açısından Değerlendirilmesi, Dokuz Eylül Üniversitesi Buca Eğitim Fakültesi Dergisi, Say1: 20, 1-10.

Yenişehirlioğlu, Ş. (1982). Felsefe ve sanat, Ankara: Dayanışma.

Yıldırım V. ve Koç T. (2011). Müzik felsefesine giriş, İstanbul: Bağlam.

Yıldırım, A. ve Şimşek, H. (2016). Sosyal bilimlerde nitel araştırma yöntemleri, Ankara: Seçkin. http://www.tdk.gov.tr/index.php?option=com_gts\&arama=gts\&guid=TDK.GTS.5bd19cae12565 7.85576679, Erişim: 25 Ekim 2018. 